\title{
СЕПСИС У ХВОРИХ ЗА УСКЛАДНЕНОГО СИНАРОМУ ДІАБЕТИЧНОЇ СТОПИ - ОКСИДАНТНИЙ СТРЕС ОРГАНІЗМУ
}

\author{
С. Д. Шаповал, О. В. Трибушний, І. Л. Савон
}

Запорізька медична академія післядипломної освіти

\section{SEPSIS IN PATIENTS WITH COMPLICATED SYNDROME OF DIABETIC FOOT - OXIDANT STRESS OF ORGANISM}

\author{
S. D. Shapoval, O. V. Trybushnyi, I. L. Savon \\ Zaporizhzhya Medical Academy of Postgraduate Education
}

\section{Рефрерат}

Вступ. Гнійні захворювання відзначають більш ніж у 35\% пацієнтів хірургічних стаціонарів, з яких особливою групоює пацієнти 3 сепсисом на тлі ускладненого синдрому діабетичної стопи (СДС). Реакція організму на септичний процес проявляється змінами метаболічних процесів, у регуляції яких важливу роль відіграють перекисне окиснення ліпідів (ПОЛ) та система антиоксидантного захисту (АОЗ).

Матеріали і методи. Обстежені в динаміці 724 хворих з приводу ускладненого СДС. Стан ПОЛ оцінювали на основі аналізу його первинних та вторинних продуктів- дієнових кон'югат (ДК), малонового діальдегіду (МДА), шифових основ (ШО).

Результати. Встановлено, що у хворих як за ускладненого СДС, так і сепсису, зміни вмісту продуктів ПОЛ в сироватці крові при госпіталізації були достовірними ( $p<0,05)$, при сепсисі, більш вираженими, ніж за ускладненого СДС без сепсису.

Обговорення. Аналіз отриманих даних свідчить, що тяжкість перебігу сепсису у хворих за ускладненого СДС залежить від стану вільнорадикального окиснення ліпідів. За результатами дослідження, первинні й вторинні продукти ПОЛ є об'єктивними маркерами тяжкості ендогенної інтоксикації, визначають оксидантний стрес організму. В системі комплексної терапії таких хворих слід застосовувати антиоксиданти як один з варіантів патогенетично обгрунтованої інтенсивної терапії.

Ключові слова: синдром діабетичної стопи; сепсис; перекисне окиснення ліпідів; оксидантний стрес.

Abstract

Introduction. Purulent diseases are noted in more than $35 \%$ of patients in surgical stationaries, of whom a special group is presented when sepsis occurs on the complicated diabetic foot syndrome (DFS) background. The organism reaction towards septic process presents as changes in metabolic processes, in regulation of which peroxidal oxidation of lipids (POL) and system of antioxidant defense (SAD) play significant role.

Materials and methods. There were examined in dynamics 724 patients, suffering complicated DFS. The POL state was estimated, basing on analysis of its primary and secondary products- dienic conjugates, malonic dyaldehyde, and Schiff bases.

Results. There was established, that in patients, suffering complicated DFS or sepsis, the changes in the POL products content in the blood sera while admittance to hospital have appeared trustworthy $(p<0.05)$ in sepsis, and more pronounced, than in complicated DFS without sepsis.

Discussion. Analysis of the data obtained witnesses, that the sepsis course severity in patients with complicated DFS depends on the state of a free-radical oxidation of lipids. Results of the investigation also trusts, that primary and secondary products of POL constitute objective markers of the endogenous intoxication severity and determine the organism oxidant stress. In system of complex therapy in such patients antioxidants must be applied as one of variants of pathogenetically substantiated intensive therapy.

Keywords: diabetic foot syndrome; sepsis; peroxidal oxidation of lipids; oxidant stress.

У теперішній час захворюваність на цукровий діабет (Цд) набула характеру пандемії. У 35\% пацієнтів, госпіталізованих у хірургічні стаціонари, відзначають гнійні захворювання, з них особливою групою є пацієнти з ускладненим СДС, що є причиною «високої» ампутації нижніх кінцівок, післяопераційна летальність становить 5- 42\% [1]. Майже у 10- 12\% пацієнтів при сепсисі виявляють порушення вуглеводного обміну. Якщо мати на увазі, що кожного року в світі реєструють $18-20$ млн. хворих на сепсис, 3 яких 4,5- 6 млн. вмирають, особливості діагнос- тики й лікування сепсису у хворих за ускладненого СДС є важливою проблемою $[2,3]$. Реакція організму на септичний процес проявляеться змінами метаболічних процесів, у регуляції яких важливу роль відіграють ПОЛ та АОЗ $[4,5]$. ПОЛ $є$ наслідком оксидантного стресу, супроводжується утворенням численних продуктів, що різняться за хімічною структурою, токсичністю та біологічною активністю. Аналіз продуктів ПОЛ представляє інтерес для оцінки вираженості оксидантного стресу в організмі, дослідження токсичної, метаболічної та регуляторної дії цього процесу на організм, а також діагностики деяких захворювань [6].

В літературі майже відсутні відомості щодо змін показників ПОЛ у хворих на сепсис, спричинений гнійно-некротичними процесами при СДС.

Мета дослідження: проаналізувати зміни показників ПОЛ у хворих за ускладненого СДС, що супроводжувався сепсисом.

\section{МАТЕРІАЛИ I МЕТОДИ ДОСЛІДЖЕННЯ}

Обстежені в динаміці 724 хворих, яких 3 приводу ускладненого СДС лі- 
кували у Гнійно-септичному центрі з ліжками для хворих з СДС Міської клінічної лікарні № 3 Запоріжжя у 2006- 2016 pp.

У 71 (9,8\%) хворого (1-ша група) виявлені ознаки сепсису, у 653 (90,2\%) пацієнтів (2-га група) ускладненого СДС без сепсису. Більшість - 517 (71,4\%) хворих були літнього віку, тривалість існування ШД II типу у середньому (12,7 \pm $2,7)$ року. Вік пацієнтів у середньому $(63,2 \pm 2,3)$ року.

Для діагностики сепсису та встановлення фази (форми) перебігу цього патологічного синдрому використовували стандартні клінічні критерії оцінки «вихідного» стану серцево-судинної, дихальної та інших систем організму.

Як обов'язкове доповнення під час формування діагнозу «тяжкий сепсис» слід описувати органну дисфункцію, оскільки характер ураження органів і систем, а також кількість ушкоджень органів відображають тяжкість стану й визначають прогноз перебігу хвороби.

При визначені сепсису використовують класифікацію R. S. Bone [7]. Сепсис діагностований у 20 (28,2\%) хворих, тяжкий сепсис- у 51 (71,8\%), септичний шок - у 14 $(27,4 \%)$ з них синдром поліорганної недостатності (СПОН) - у 9 (17,6\%).

Причиною сепсису у хворих за ускладненого СДС була переважно волога гангрена нижніх кінцівок.

Стан процесів ПОЛ оцінювали на підставі вивчення рівня його первинних та вторинних продуктів- ДК, МДА, ШО. ДК визначали за методом В. В. Гаврилова (1988). Гідроперекиси ліпідов (ГПЛ) екстра- гували з сироватки крові за допомогою суміші гептан-ізопропіловий спирт. Як інгібітор вільнорадикального окиснення ліпідів використовували ЕДТА (1 мг/мл). Результати виражали у відносних одиницях оптичної щільності на 1 мл сироватки крові. Концентрацію МДА визначали в реакції з 2-тіобарбітуровою кислотою з утворенням забарвленого тримежинового комплексу з максимумом поглинання при 522 нм та молярним коефіцієнтом екстинкціï 1,56 × $10^{5}$ н/см. Отримані результати обчислювали в 1 мл сироватки (Я. И. Андреева та співавт., 1988), виражали в мкмоль/л. ШО визначали на спектрофотометрі (A. S. Csallemy, K. J. Ayar, 1976) в умовних одиницях. Результати зіставляли з рівнем загальних ліпідів (3Л) у сироватці крові, що визначали 3 використанням стандартних наборів реактивів виробництва фірми «Lackema» (Чехія). Оптичну щільність забарвленого комплексу вимірювали на спектрофотометрі, результати виражали в г/л.

Показники ПОЛ в нормі визначали у 18 донорів.

Дослідження проводили при госпіталізації хворих, на 7-8-му і 1216-ту добу лікування.

Статистичний аналіз проведений з використанням програмного пакета Statgraphics Plus for Windows 7,0.

\section{РЕЗУЛЬТАТИ \\ ТА ÏХ ОБГОВОРЕННЯ}

У хворих як за ускладненого СДС, так і сепсису, зміни вмісту продуктів ПОЛ у сироватці крові при госпіталізації були достовірними (див. таблицю).
При сепсисі ці зміни були більш виражені, ніж за ускладненого СДС без сепсису.

3 хворих, які померли від сепсису в перші години після госпіталізації, у 15 (35,7\%) зміни показників ПОЛ були дегенеративними, спостерігали як надзвичайно високий рівень продуктів ПОЛ, так і надто низький, у деяких спостереженнях показники як первинних, так і вторинних продуктів ПОЛ визначити не вдалося.

Після санації гнійного вогнища за ускладненого СДС та, як правило, високої ампутації нижньої кінцівки 3 приводу вологої гангрени у хворих на сепсис, на 7-8-му добу спостерігали тенденцію до нормалізації досліджуваних показників, у хворих за ускладненого СДС - більш виражену $(\mathrm{p}<0,05)$.

Проте, тільки санація патологічного вогнища не забезпечувала значне зменшення вмісту продуктів ПОЛ, що, можливо, зумовлене метаболічними розладами, спричиненими екзогенною токсемією. При ii усуненні відзначали інактивацію надлишку продуктів ПОЛ, починаючи з 5- 7-ї доби після операції.

На 12-16-ту добу показники ПОЛ у пацієнтів за ускладненого СДС все ще суттево відрізнялися від таких у контролі, їх нормалізації не було. У хворих на сепсис, які одужали, зазначені зміни були більш виражені, проте, суттєво не відрізнялися від аналогічних показників у пацієнтів за ускладненого СДС ( $\mathrm{p}>0,05)$.

За надмірної кількості продуктів ПОЛ порушується функція біомембран з подальшим формуванням СПОН. Дезорганізація клітинних мембран у хворих на сепсис та ре-

Показники ПОЛ у хворих за ускладненого СДС та сепсису

\begin{tabular}{|c|c|c|c|c|c|c|c|}
\hline \multirow[b]{3}{*}{ Показник } & \multirow{3}{*}{$\begin{array}{c}\text { контрольній } \\
(\mathrm{n}=18)\end{array}$} & \multicolumn{6}{|c|}{ Величина показника групах ( $\bar{x} \pm m)$} \\
\hline & & \multicolumn{3}{|c|}{ 1-й } & \multicolumn{3}{|c|}{$2-\bar{и}$} \\
\hline & & $\begin{array}{c}\text { при } \\
\text { госпіталізації } \\
(\mathrm{n}=26) \\
\end{array}$ & $\begin{array}{c}\text { на 7-8-му } \\
\text { добу } \\
(n=23)\end{array}$ & $\begin{array}{c}\text { на } 12-16-\text { ту } \\
\text { добу } \\
(n=19) \\
\end{array}$ & $\begin{array}{c}\text { при } \\
\text { госпіталізації } \\
(\mathrm{n}=34) \\
\end{array}$ & $\begin{array}{c}\text { на 7-8-му } \\
\text { добу } \\
(n=32) \\
\end{array}$ & $\begin{array}{c}\text { на } 12-16-\text {-ту } \\
\text { добу } \\
(n=27)\end{array}$ \\
\hline ГПЛ 233, мл & $3,53 \pm 0,23$ & $6,03 \pm 0,57$ & $5,24 \pm 0,27$ & $3,92 \pm 0,34$ & $5,12 \pm 0,27^{* \Delta}$ & $4,73 \pm 0,16^{* \Delta}$ & $3,74 \pm 0,21^{* \Delta}$ \\
\hline $\begin{array}{l}\text { ГПЛ } 233 \\
\text { в } 1 \text { мл ліпідів }\end{array}$ & $1,04 \pm 0,01$ & $1,77 \pm 0,23$ & $1,41 \pm 0,33^{*}$ & $1,18 \pm 0,16^{*}$ & $1,42 \pm 0,17^{*}$ & $1,31 \pm 0,22^{*}$ & $1,19 \pm 0,13^{*}$ \\
\hline ГПЛ 273, мл & $0,63 \pm 0,06$ & $1,34 \pm 0,17$ & $1,24 \pm 0,21$ & $0,79 \pm 0,04^{*}$ & $1,02 \pm 0,09 *^{\Delta}$ & $0,98 \pm 0,14^{*^{\Delta}}$ & $0,81 \pm 0,07^{*}$ \\
\hline 3Л, г/л & $3,72 \pm 0,31$ & $4,37 \pm 0,19 *$ & $4,03 \pm 0,34^{*}$ & $3,87 \pm 0,14^{*}$ & $4,32 \pm 0,23^{*}$ & $4,14 \pm 0,17^{*}$ & $3,98 \pm 0,31^{*}$ \\
\hline $\begin{array}{l}\text { МДА, } \\
\text { мкмоль/л }\end{array}$ & $10,47 \pm 0,34$ & $16,27 \pm 0,23$ & $16,08 \pm 0,74^{*}$ & $16,06 \pm 0,62$ & $15,04 \pm 1,03^{* \Delta}$ & $15,12 \pm 0,62^{*}$ & $13,81 \pm 1,06^{*}$ \\
\hline ШО, ум.од. & $7,21 \pm 0,69$ & $10,12 \pm 0,37 *$ & $9,23 \pm 0,17^{*}$ & $9,27 \pm 0,08$ & $10,13 \pm 0,43^{*}$ & $9,29 \pm 0,34^{*}$ & $8,16 \pm 0,67^{* \Delta}$ \\
\hline
\end{tabular}


гуляторних механізмів ПОЛ зумовлена також впливом як екзогенних, так і мембраностабілізуючих механізмів.

Аналіз отриманих даних свідчив, що виникнення сепсису у хворих за ускладненого СДС багато в чому залежить від стану вільнорадикального окиснення ліпідів, вони відіграють роль регуляторного механізму запальної реакції, що змінює про-

\section{REFERENCES}

1. Boyko VV, Ivanova YuV, Avdosev Yu V. Kompleksnoe hirurgicheskoe lechenie sindroma diabeticheskoy stopyi [Complex surgical treatment of diabetic foot syndrome]. Hirurgichna perspektiva. 2014;1(8): 3-10. [In Russian].

2. Mjurrej P. Molekuljarnye i nemolekuljarnye metody $v$ diagnostike infekcij krovotoka. Simpozium: «Sepsis i infekcii krovotoka». XVII Mezhdunarodnij kongress MAKMAH po antimikrobnoj terapii. Moskva, 22 maja 2014. [In Russian].

3. Dellinger RP, Levy MM, Rhodes A. Surviving sepsis campaign: International guidelines for management of severe sepsis and septic shock: 2012. Crit Care Med. 2013 Feb.; 41(2):580-637.

4. Podilchak MD, Makar DA, Ohonovskyi VK, Kordoba BM. Perekysne okyslennia lipidiv ta aktyvnist peroksydazy syvorotky krovi
2. Зміни показників ПОЛ у комплексі 3 іншими даними клініко-лабораторних досліджень свідчать про тяжкість перебігу гнійного процесу, дозволяють оцінити ефективність терапії.

3. В комплексі терапії хворих обох груп слід застосовувати різні антиоксиданти як один з варіантів патогенетично обгрунтованої інтенсивної терапії. u khvorykh z hniino-zapalnymy urazhenniamy. Klinichna khirurhiia. 1995;(2):11-12. [In Ukrainian].

5. Shapoval SD. Perekisnoe okislennje lipidov i sostojanie antioksidantnoj sistemy pri sepsise u bolnyh $\mathrm{s}$ gnojno-vospalitelnym porazheniem mjagkih tkanej. Klinichna hirurhiia. 1998;(11):15-6. [In Russian].

6. Nekrasov YeV. Metody analiza perekisnogo okislenija lipidov $v$ mediko-biologicheskih issledovanijah. Bjulleten. 2012; vyp. 46:98-108. [In Russian].

7. Bone RC. The pathogenesis of sepsis. Ann Int Med. 1991;115:45969. 